\title{
Malaysian geotourism - The Langkawi Geopark as a model area
}

\author{
Malgorzata Mordal \\ University of Warsaw, Faculty of Geography and Regional Studies, \\ ul. Krakowskie Przedmieście 30, 00-927 Warszawa; \\ e-mail:malgorzatamordal@o2.pl
}
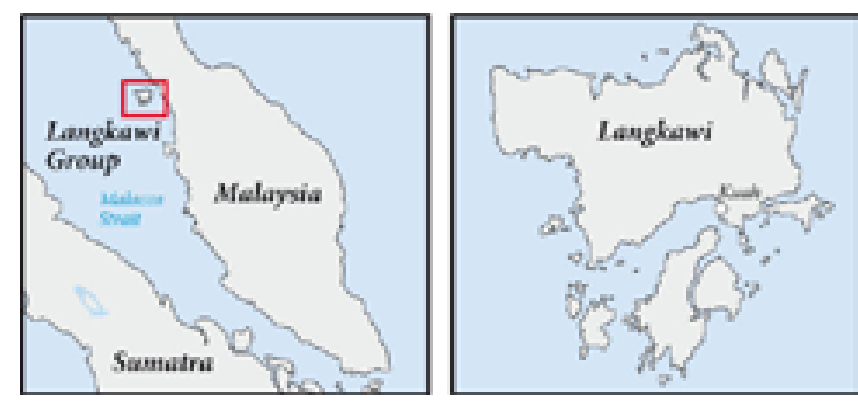

Abstract: The Langkawi Geopark is one of the first geoparks in the region, created under the auspices of UNESCO and can be considered as a role model not only in South East Asia, but also on a global scale. Presently, the approach towards tourism is holistic, therefore, combining the benefits for the environment, local population and tourists (under the idea of sustainable tourism generally and geotourism in particularly) is essential. On the Langkawi Islands, natural conditions for the development of geotourism are outstanding. They exhibit all the major rock types, beginning with those from the Cambrian period, fossil and faults. The most important however, is the fact that all those geological features are well exposed, and they are easy to reach, since the infrastructure on the island is developed excellently. This paper presents the strategy of development of sustainable tourism / geotourism at the governmental level, the geographical settings of Langkawi and geology of Langkawi, infrastructure of Langkawi Geopark and its applied use.

Key words: geopark, geotourism, Malaysia, Langkawi, sustainable tourism, geotouristic attraction

\section{Introduction}

Geological resources and their proceeded products are essential elements in peoples' everyday life. Many civilizations had developed because of mineral and rock resources. Contemporary societies still rely on geological resources as essential commodities for their existence and development. The demand for geological resources has been growing over the years, together with an increasing number of people on our planet. To be able to satisfy the request for natural goods of the Earth, we need to deepen our knowledge in this matter, as well as share the knowledge with as many people as possible.

Geological conservation is more advanced in countries of higher economic development as:
1) the consciousness of its importance is higher;

2) the less developed countries still rely more on the secondary sector of the economy rather than the tertiary.

Presently, as we all became a part of the global village, we need to learn to protect the Earth as a unity. Geotourism is a new form of active tourism. Its popularity has been increasing firmly and steadily. Its basis lays in sustainable use of natural heritage. It promotes awareness and knowledge, through studying, interpretation and experience. It is one of the conscious way of sightseeing that puts the $3 \mathrm{xE}$ (Entertainment, Excitement, Education) rule in front of the $3 \times \mathrm{xS}$ (Sun, Sea, Sand) rule. For putting the idea of geotourism into practice, the tourist product as a tool for the idea of development had to be created. The answer for this is the "Geopark", which, according to UNESCO is: "a nationally protected area containing a number of geological heritage sites of particular importance, rarity or aesthetic appeal". The geological site of a geopark is a part of more complex concept of protection, education and sustainable development. A geopark is meant to achieve those goals through geotourism that include conservation and education.

\section{Strategy of ecotourism development in Malaysia}

Until the 1990s, the tourism in Malaysia was focused on mass tourism in places such as Penang, but also in Langkawi. In 1999, the successful brand "Malaysia Truly Asia" was launched. It raised interest among the western world and made Malaysia one of the most popular destination in this part of the world. Presently, tourism in Malaysia generates 4.8 percent of GDP and employs 4.9 percent of the population (www 1) (Figs 1, 2).

Malaysia has competitive advantages to develop ecotourism, such as tourist infrastructure, which is best developed in the region, natural and cultural resources, quite good government priorities towards Travel of Tourism, excellent environmental regulation and potential in human resources (www 2).

Currently, ecotourism is the area of tourism, which the government focuses on. In 1995, the National Ecotourism Plan was agreed. It indicated 52 places in Malaysia with the potential for the development of ecotourism. The 7th Malaysia 
Plan 1996-2000 assumed that the government would provide basic infrastructure, and the private sector would strongly support the National Ecotourism Plan (www 3). The 8th Malaysia Plan 2001-2005 considered policy for sustainable development and promoting Malaysia as an ecotourism destination. Apart from that, the Malaysian government launched new touristic products, offering foreign visitors to a stay with Malaysian families in villages (www 4). In the 9th Malaysia Plan 2006-2010, the government increased further its efforts towards ecotourism growth by giving state tourism councils a stronger role and encouraging local authorities to be more involved in tourism development and environmental protection (www 5).

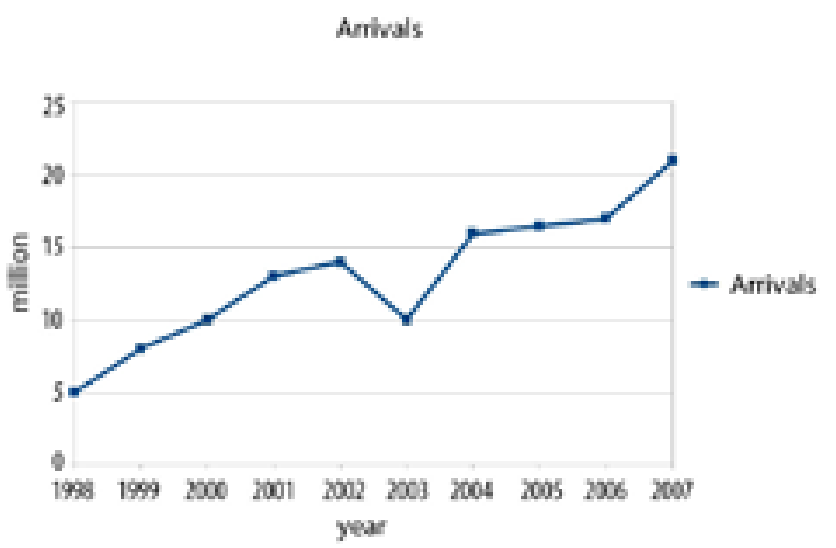

Fig. 1. International arrivals in Malaysia year by year (source: www 1)

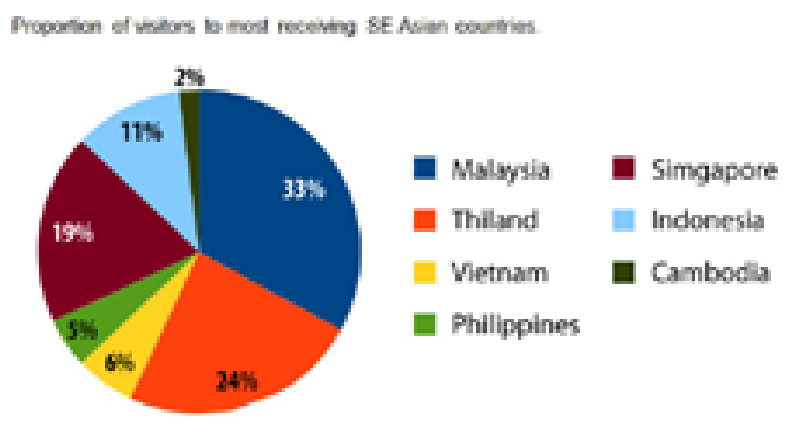

Fig. 2. Proportion of visitors arriving in different Asian countries (source: www 1)

The government promotes Malaysia as an ecotourism destination, with a separate section devoted to tourism on the federal website.

General environmental awareness in Malaysia is low and interest in national heritage sites is also low, although there are attempts to make it an integrated part of all education (Daniel \& Nadeson, 2006). With time, people should become more aware that the natural environment is the main reason for the arrival of tourists. According to FAO 1998, 7-10\% of all tourists in Malaysia were considered as ecotourists. The vast majority of them came from the western part of the world.

To sum up, Malaysia has excellent conditions to develop ecotourism, such as the natural environment and governmental regulations, but there is a gap between legislation and the common understanding of ecotourism and sustainable development by local communities. Ecotourism was the fastest growing segments of tourism. It was increasing 35\% per year, and it constituted $10 \%$ of tourism in Malaysia (www 6).

In the past, the awareness of importance of geological heritage was rather low (Marker M.A. et al., 2008). Consequently, important geoheritage sites were lost, mainly due to improving economic growth. The breakthrough in this matter came after the 1992 Rio Summit. It brought into light the need for natural conservation in Malaysia. In 1996, Malaysian Geological Heritage Group (MGHG) was formed by geoscientists. This date can be considered as the initiation of geotourism in Malaysia.

The main activity of the group was lobbying the decision makers on the importance of geoheritage conservation, as well as educating the public on heritage values of the Malaysian landscape and other geological features. Along with the growing influence of MGHG, they manage to convince the decision makers to:

- create a national geoheritage database - Mineral and Geoscience Department;

- include several geoheritage sites in the National Heritage List - Heritage Department;

- formulate the Geoforest Park Concept - Forestry Department of Peninsular Malaysia;

- create the Langkawi Geopark - Kedah State Government and Langkawi Development Authority.

All the undertaken projects made Malaysia internationally important as a geotourist destination.

\section{The geographical settings of Langkawi Islands}

Langkawi is an archipelago, located in northwest Malaysia, made up of 99 islands; while another 5 are exposed during low tide. There are other brand names in use for the archipelago, for instance Isles of Legend, Duty Free Islands, Tourism City and 99 Magical Islands (Leman et al., 2007). The archipelago is geographically situated between latitude $6^{\circ} 10^{\prime} \mathrm{N}$ to $6^{\circ} 30^{\prime} \mathrm{N}$ and longitude $99^{\circ} 35^{\prime} \mathrm{E}$ to $100^{\circ} \mathrm{E}$. The land area of Langkawi archipelago is $478 \mathrm{~km}^{2}$ (www 7) (Fig. 3). Administratively, the Langkawi archipelago is within the State of Kedah and is divided into six sub-districts. The weather conditions are the same as in the mainland of the Peninsular Malaysia. The temperature ranges from $22,5^{\circ} \mathrm{C}$ to $34,5^{\circ} \mathrm{C}$, and its monthly rainfall ranges from $69 \mathrm{~mm}$ during the dry season (December - March) to $870 \mathrm{~mm}$ (September to November) (Fig. 4). 


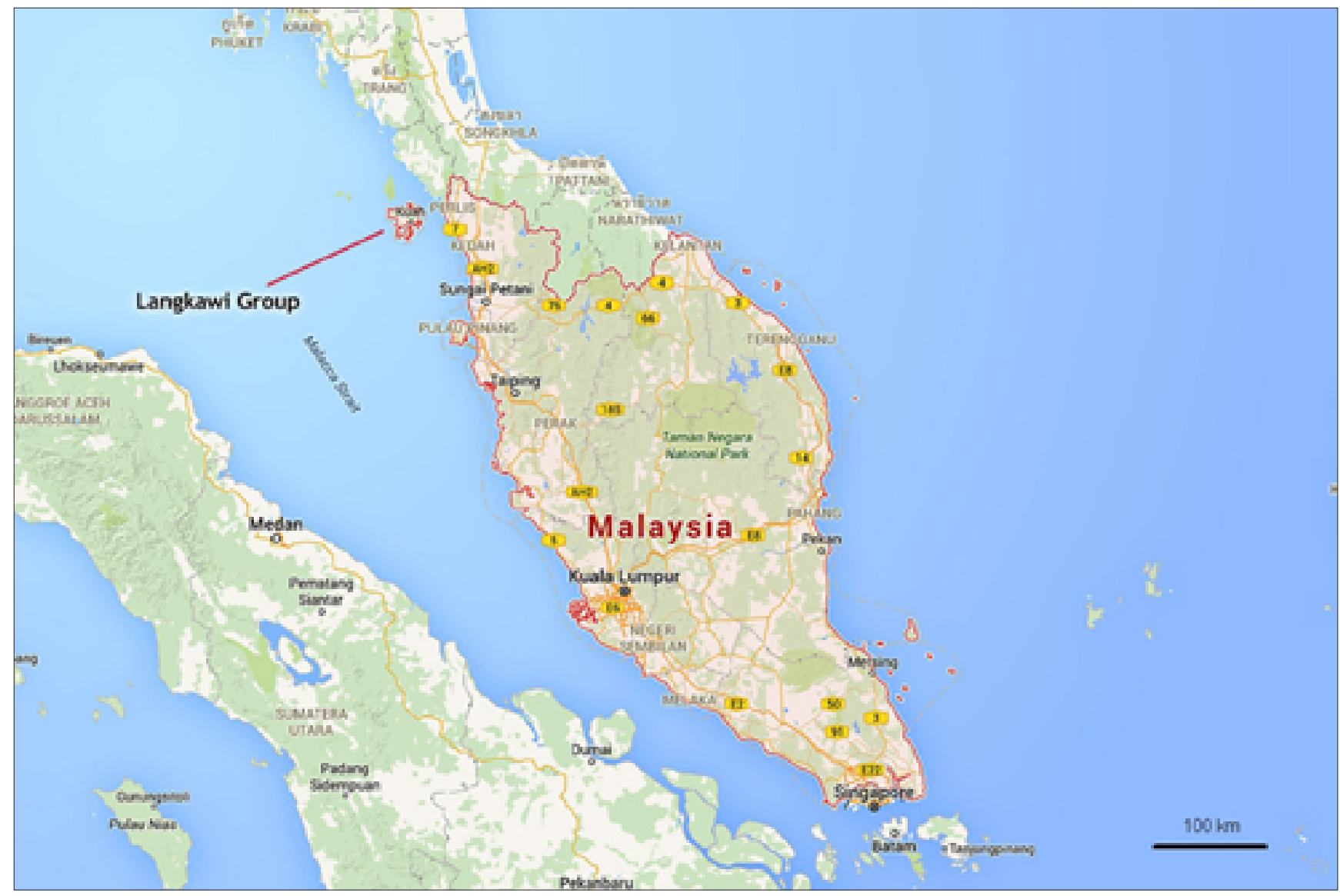

Fig. 3. Location of Langkawi Island (source: www 7)

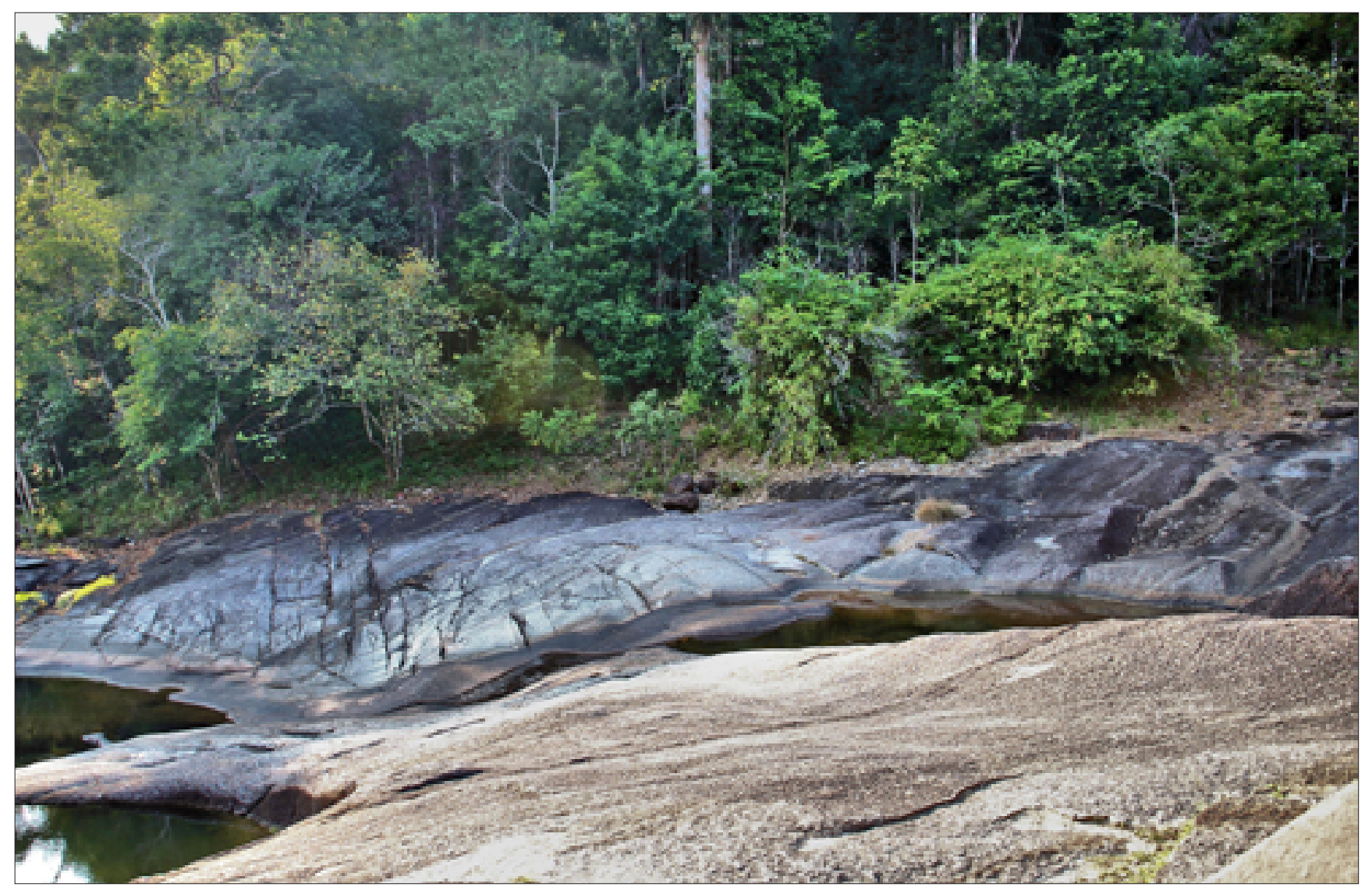

Fig. 4. Telaga Tujuh waterfall during the dry season, photo M. Mordal 
Since the Langkawi archipelago experiences a slightly longer dry season, and because it is built of particular weather-resistant bedrock, it supports a variety of natural landscapes. The Machinchang sandstone, Setul limestone and Chuping marble are more resistant, and they present the landscape of barren rocks. Granite and mudstone are less resistant, which has resulted in the development of a thicker layer of soil. Nutrients and water kept in the soil allowed vegetation to have a more permanent character and to be more resistant to droughts. The combination of different resistant rocks allowed the present geological landscape to be created.

The flora in Langkawi is influenced mainly by bedrock, climate, topography, soil, relief and human activity. The main two terrestrial habitats are mangroves (3,142 hectares) (Fig. 5) and inland forest (23,760 hectares) (www 8). Langkawi is characterized by relatively high endemism. Before Langkawi became separated from the mainland, it had the same flora and fauna as the rest of the Malaysian Peninsula. However, as soon as the process of separation started, on the Langkawi archipelago, more endemic spices have appeared (Figs 6, 7).

Although the Langkawi archipelago is made up of 99 islands, only 3 are occupied by people: Pulau Langkawi (main island), Pulau Tuba and Pulau Dayang Bunting. The population of the Langkawi islands is 86,125 persons (www 9) and has been growing as a result of economic development of the region, mainly in the tourism industry. Langkawi has multi-racial, multi-religion and multi-cultural society, with the majority of Malays $-87,9 \%$. The main ethnic minorities are: Chinese $-5,9 \%$ and Indians $-2,2 \%$. The masculinity rate is 104 (www 10). The economic situation changed drastically after 1987, when Langkawi was proclaimed a Duty Free Island. Since then, the population of Langkawi has been growing. The pattern of employment has changed significantly. The island that started as a fishing village (primary sector) changed into a vibrant tourist destination, with the highest employment in tourism and hospitality (tertiary sector). Langkawi Development Authority, together with local authorities has involved local communities in the growing tourism industry, for instance in the hospitality sector, tour guiding and boat operation. In 2006, the Langkawi archipelago was visited by 2, 112, 026 tourists, and the number is growing. The only exception was the year 2003, when the visible decline was observed as a result of Avian Flu and worldwide threats of terrorism. So far, the Langkawi Island were the main recipients of mass tourism, but promoting the Langkawi Geopark as a sustainable tourist destination, with an awareness of protection and conservation of the natural environment brings promising perspectives for the islands to be known world-wide as a center of geotourism.

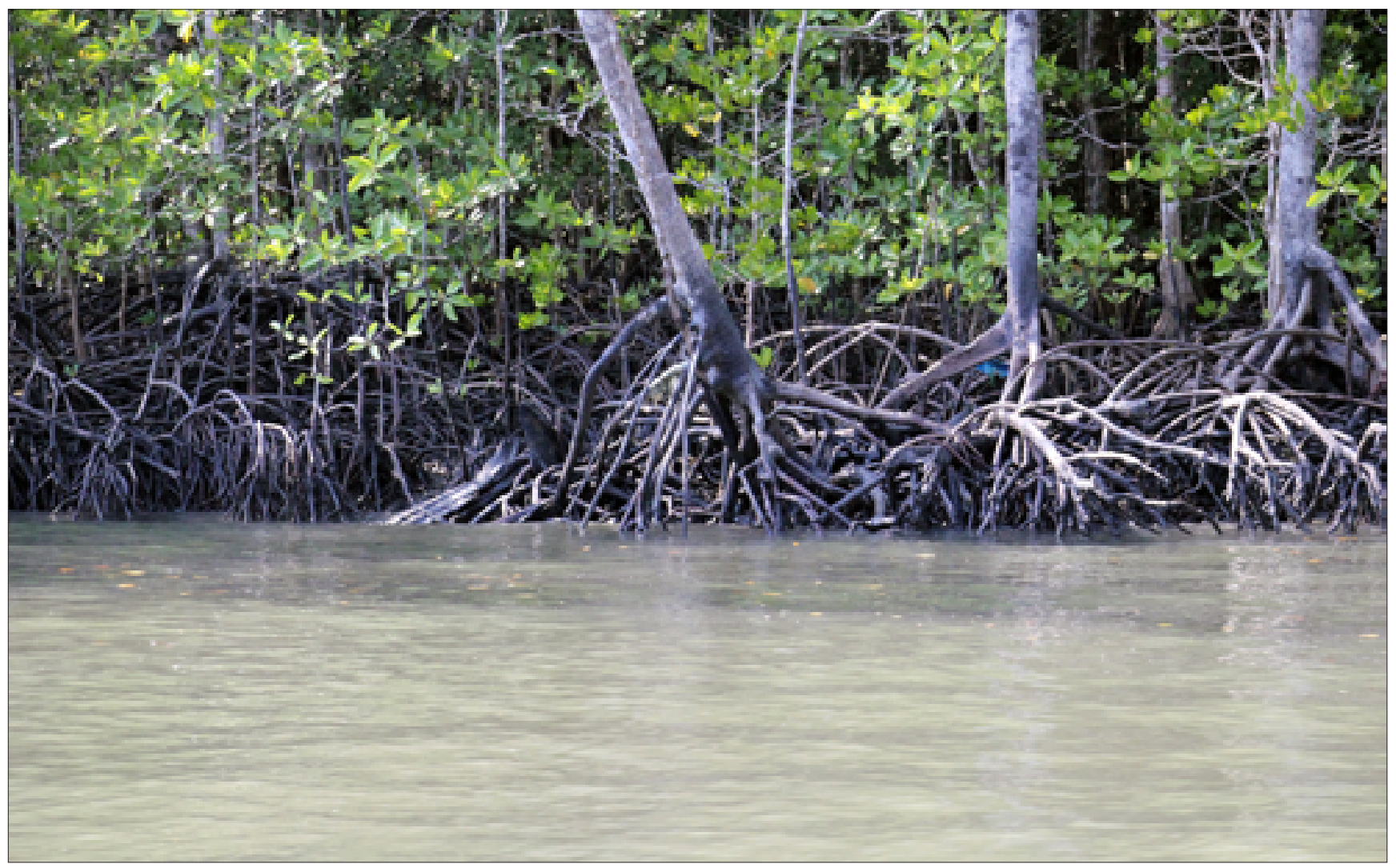

Fig. 5. Mangroves at low tide, photo M. Mordal 


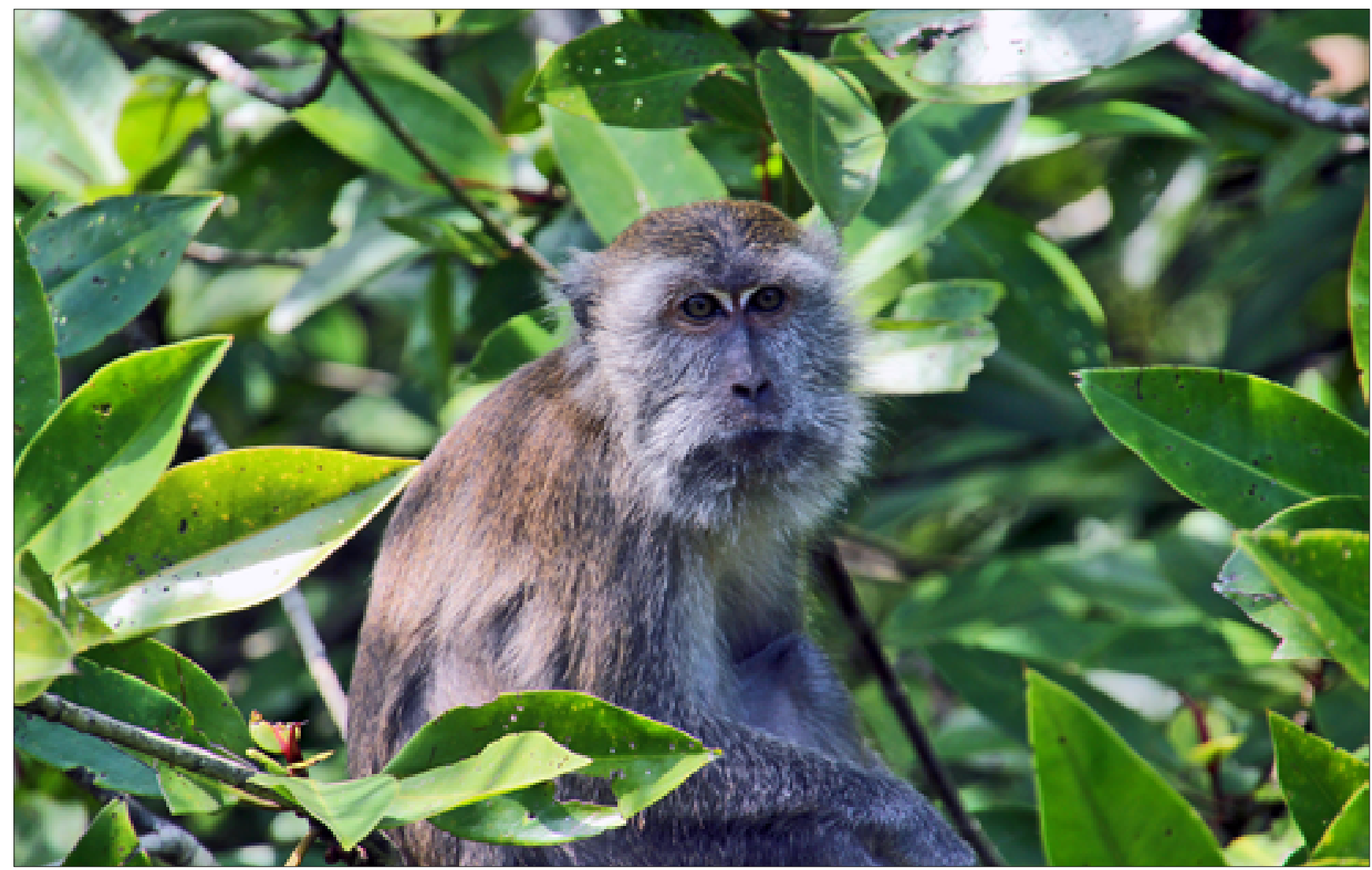

Fig. 6. Macaca Fascicularis - Crab-eating Macaque, photo M. Mordal

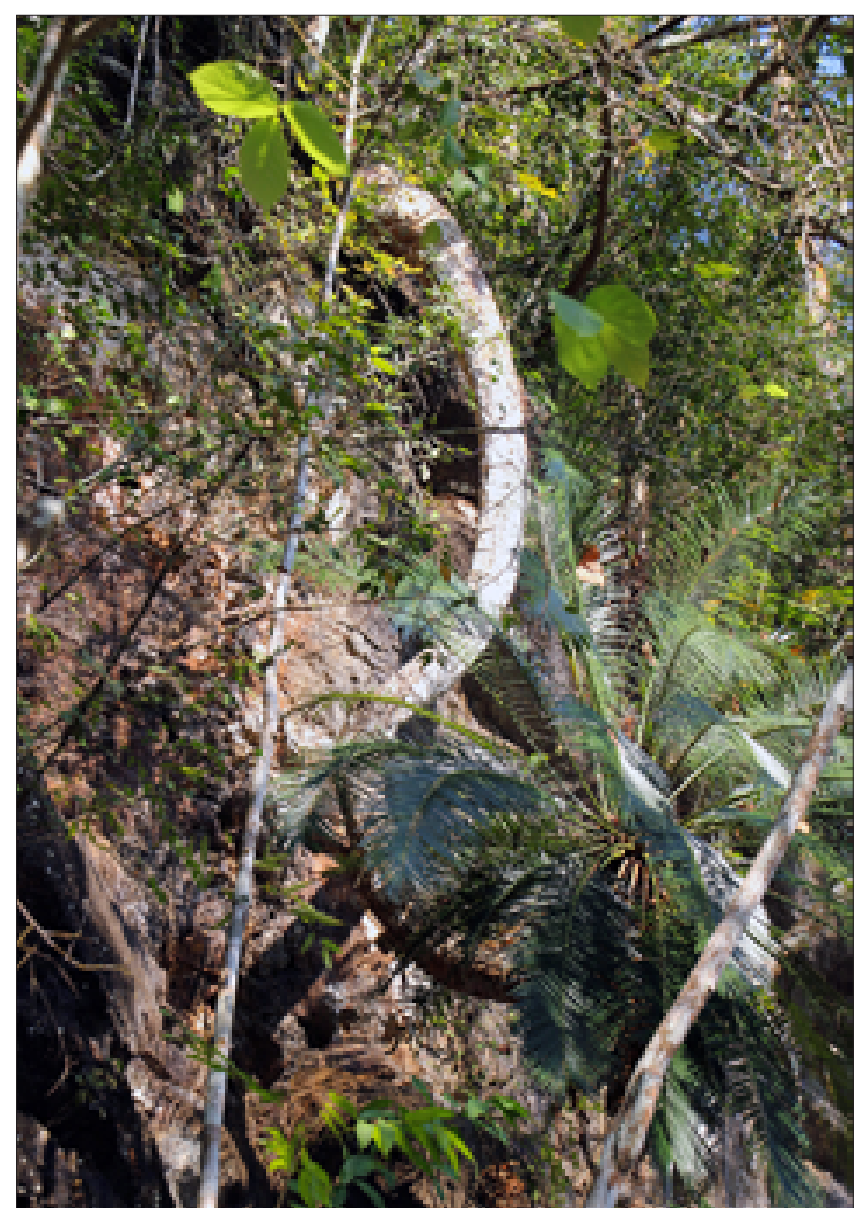

Fig. 7. Cycas Clivicola - living fossil, photo M. Mordal

\section{Geology of Langkawi}

The research on the geology of the Langkawi Islands was initiated in 1950s as a part of broader mapping project of Perlis State and the north part of Kedah (Fig. 8). This project was completed in a monograph of Langkawi geology published in 1981 (Jones, 1981). After the publication, an interest in Langkawi brought scientists from other parts of the world, such as Japan, USA and Great Britain. In 1996, the Malaysian Geological Heritage Group undertook the task of describing various aspects of Langkawi geoheritage. The outcome of it was the book "Geological Heritage of Langkawi", published in 2003. The same group began to put effort into creating the first Geopark in south-east Asia, that was inaugurated in 2006. Generally, the Langkawi archipelago possesses beautiful geological landscapes, unique geodiversity and an interesting history.

Since the Langkawi archipelago went through various geological events and processes, such as tectonic and magmatic movements and finally weathering process, the contemporary landscape is highly diverse. The islands are built of all types of rocks: igneous, sedimentary and metamorphic, with large numbers of minerals and fossils, as well as depositional and deformational structures (Fig. 9).

The geological setting of the Langkawi archipelago began 550 million years ago, during the Cambrian period, when 
the archipelago was a part of Gondwanaland in the northern hemisphere. 350 million years ago, during the Carboniferous, Gondwanaland moved to the cold south. 280 million years ago, during the Permian, a part of Gondwanaland called Sibumasu Block disintegrated and started floating towards the equatorial zone, until it collided with the East Malaya - Indochina Block, in the Late Triassic. This was followed by massive granitoid emplacement and landmass uplift (www 11) (Fig. 10).

The geology of the Langkawi archipelago can be divided into:
- 4 sedimentary formations:

- Manchanching Formation (Cambrian sand/clay/ quartzite),

- Setul Formation (Ordovician and Silurian schist/slate/ limestone),

- Singa Formation (late Devonian and carboniferous mudstone/siltstone/shale),

- Alluvium (Quaternary sands and clays);

- 1 igneous formation:

- Granite (Triassic);

- 1 metamorphic formation:

- Chuping Formation (Permian and Triassic crystalline limestone - marble).

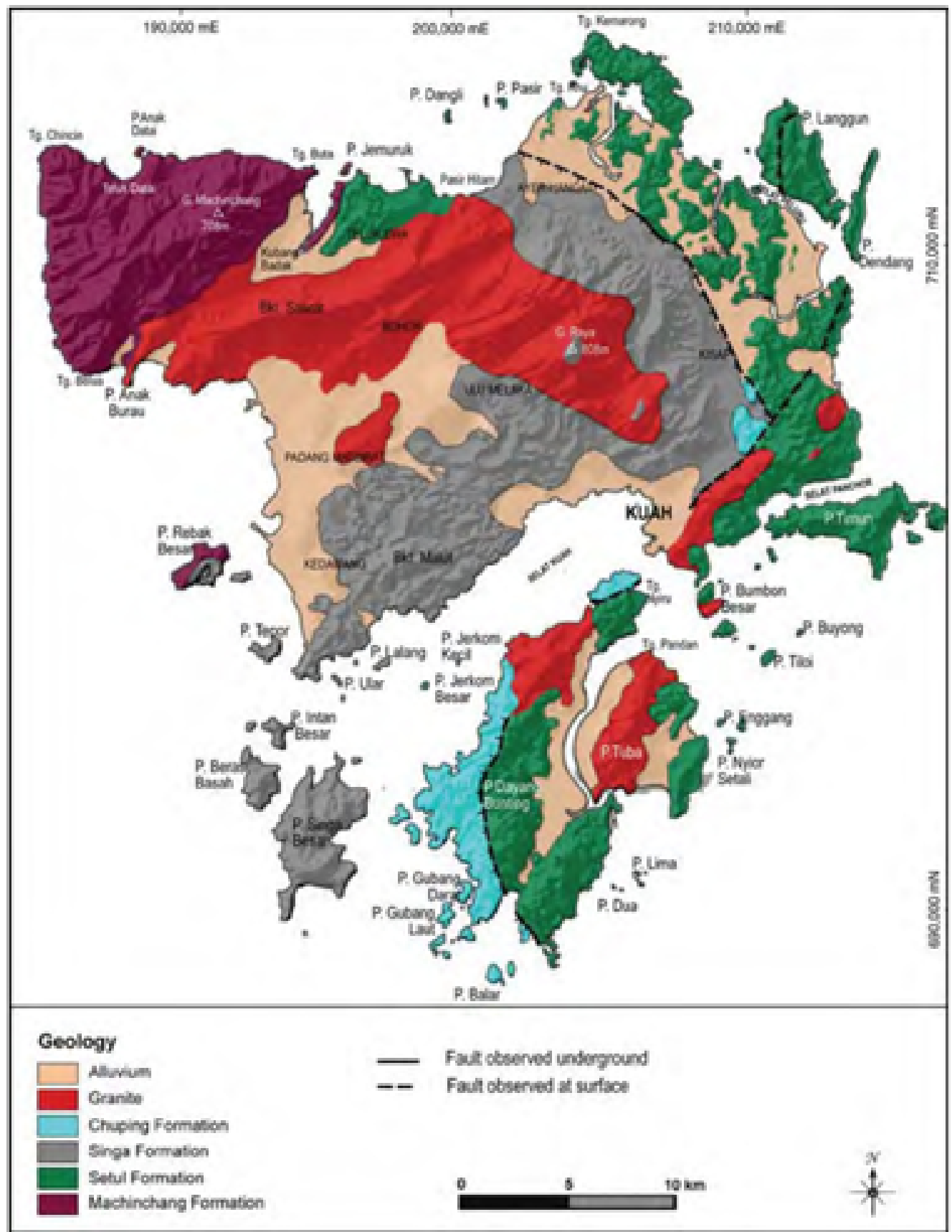

Fig. 8. Geological map of Langkawi (source: Geological Survey of Malaysia, Directorate of National Mapping, Malaysia 1985, after Jones 1981) 


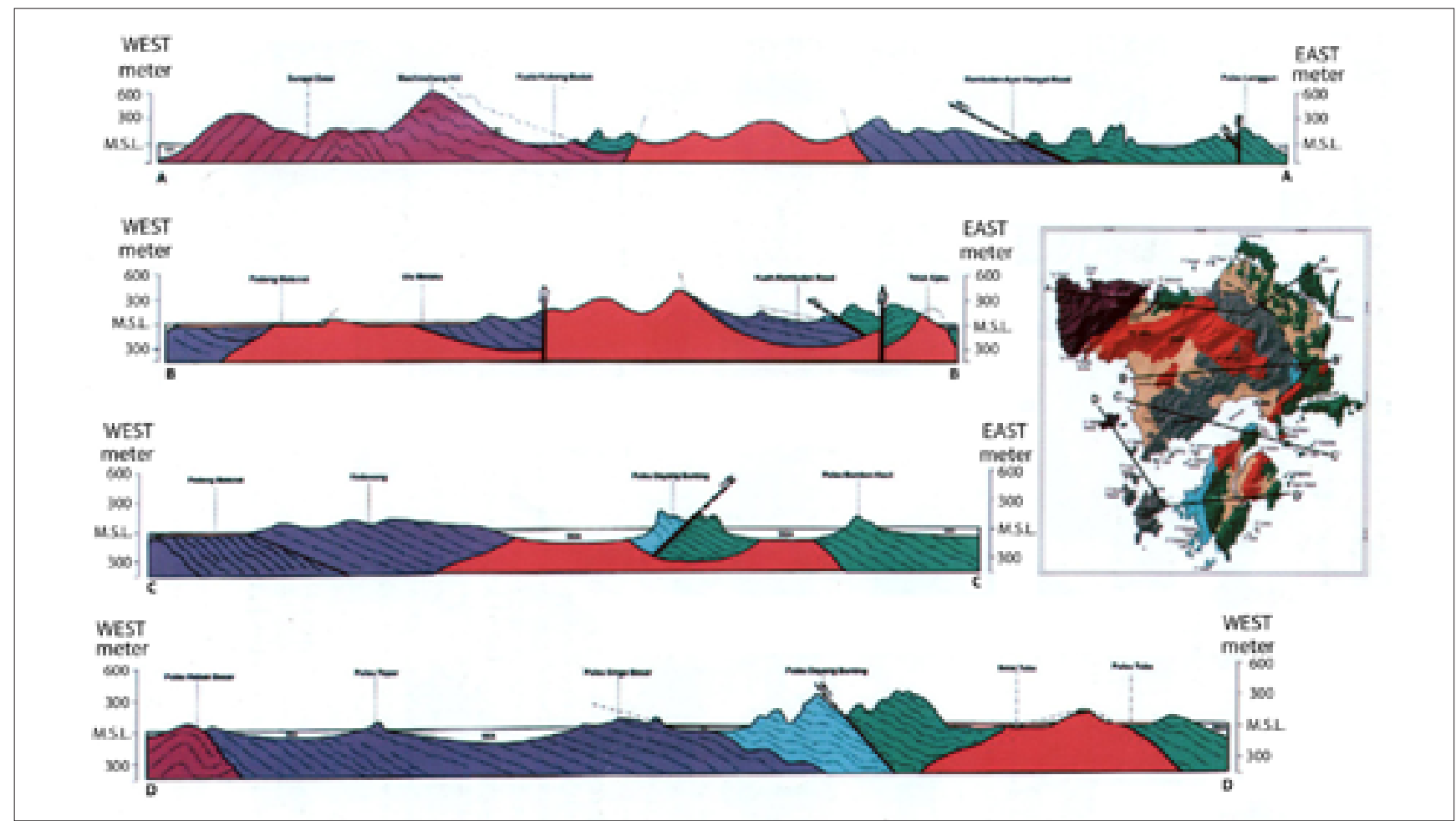

Fig. 9. Geological cross - sections across Langkawi Islands (after Jones 1981), for geological explanation see Figure 8

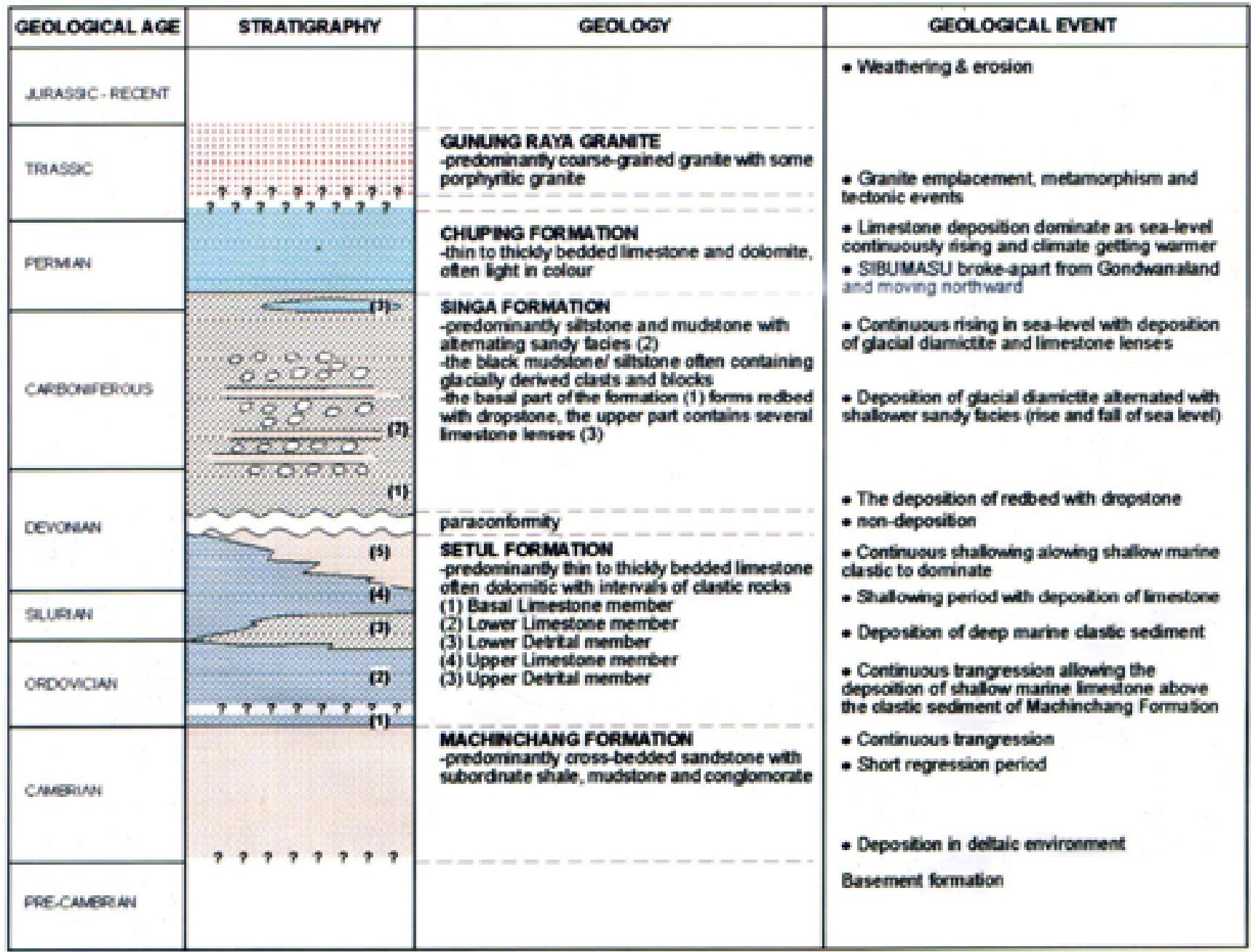

Fig. 10. Stratigraphy and major events in the history of the geology of Langkawi Islands (source: www 11) 
The Kisap Thrust Fault disturbed the chronology of depositional structures dramatically by bringing the older Manchanching and Setul Formation over the younger Singa and Chumping Formation (Leman et al., 2008).

The Machinchang Formation was named by Jones in 1961, after the mountainous area in the northwestern part of the Langkawi island, known as the Machinchang Mountains. The formation covers the Machinchang Mountains and the northern part of Pulau Rebak. The Machinchang Formation is mainly made of Cambrian sandstones, shales and quartzites. It is the oldest formation found on the
Langkawi archipelago, and also in Malaysia. Its age was established on the basis of fossils (brachiopods and trilobites). The thickness of the formation reaches up to $2830 \mathrm{~m}$ (Lee, 1983). Several hundreds of meters of undisturbed sedimentary rock successions can be observed in the Machinchang Formation (Fig. 11). However, the age of the formation made many various deformations and metamorphisms possible. The most common sedimentary structures are cross-beddings, ripple marks and erosional tafoni. Among the most common deformational (secondary) structures are different types of faults.

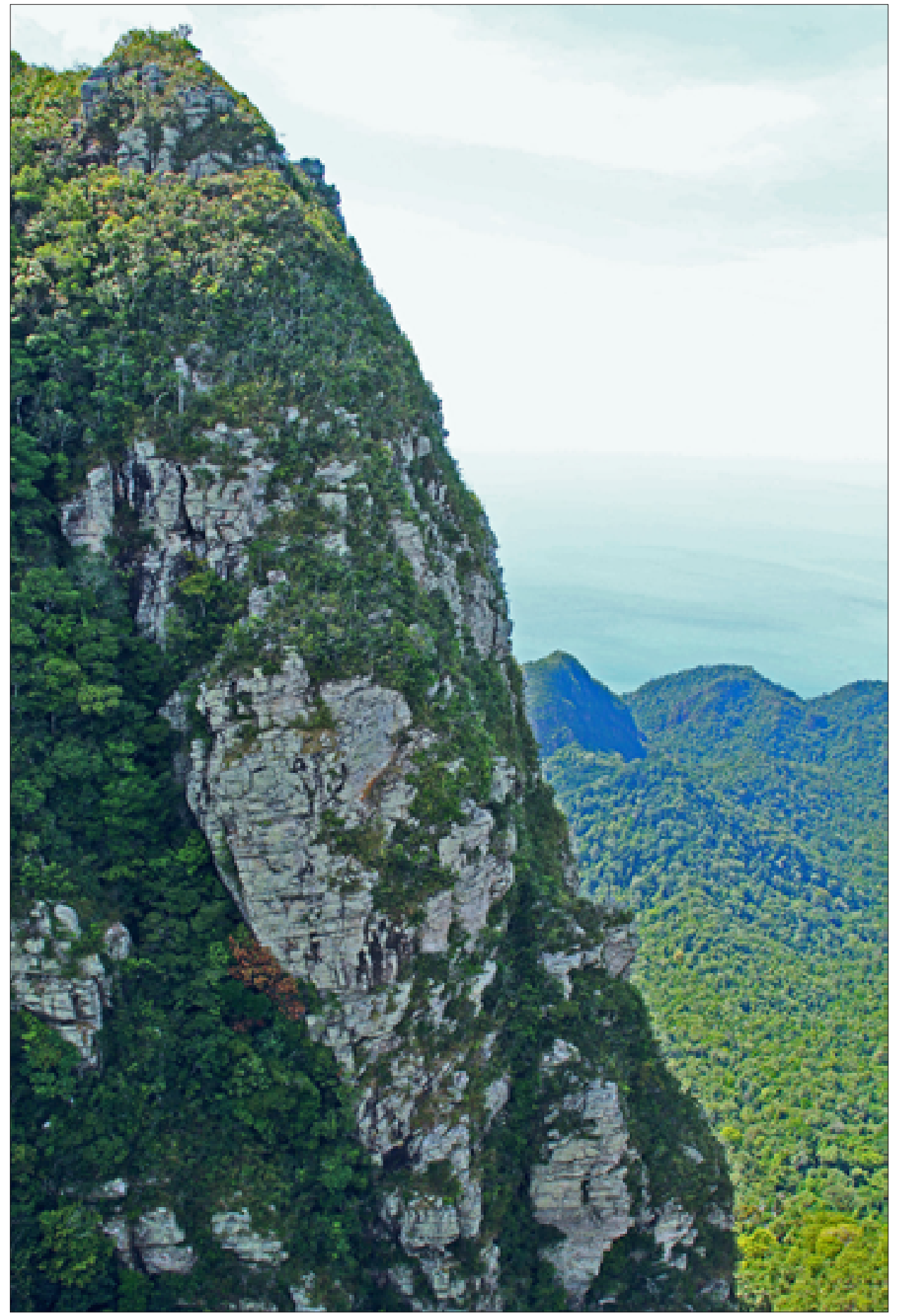

Fig. 11. Palaeozoic rock formation at Machinchang Cambrian Geoforest Park, photo M. Mordal 
The Setul Formation is the oldest limestone formation in Malaysia and the nearby region. It is situated in the eastern part of the Langkawi, extending from the islands in Tanjung Rhu in the north, to Pulau Dayang in the south. The formation was named by Jones in 1981, after the Satun Province in Thailand, which by the local Malaysian was called Steul. The total thickness of the formation is estimated to be about $1550 \mathrm{~m}$ (Jones, 1981). The formation consist mainly of limestone that was deposited from the Early Ordovician to the Middle Devonian. The Setul Formation does not exhibit many sedimentary structures.

There are some rare cross-beddings and stylolites. The most interesting form created in the Setul Formation are products of limestone dissolution (Fig. 12) and surface erosion. Among them, we can differentiate between those created by the sea, such as sea-stacks (Fig. 13), sea-caves (Fig. 14), seaarches etc., and by fresh water onshore, such as limestone pinnacles and caves, as well as underground karst forms, such as columns, stalactites, karst springs, tunnels etc. Extensive dissolution of limestone brought to the surface many fossils, for instance, gastropods, trilobite and lobolith.

The Singa Formation was named after the Pulau Singa Besar for the predominantly black color shale and siltstone (Jones, 1961). The Singa formation forms a cap over the Gunung Raya granite in the central part of the Langkawi main island and is also widely distributed in the southwestern part of the archipelago. The total thickness of the formation is estimated to be $2100 \mathrm{~m}$. It is mainly made of upper Devonian and Carboniferous mudstone, siltstone and shale. In this thickly bedded, dark gray to black layer of mudstone and siltstone, clasts of different origin, shape and size can be found. The diversity of clasts proves that they had to be brought by ice-sheets. The sedimentary structures amongst the Singa Formation also indicate fast deposition of mudstone, due to the period of polar melting and thin layers of sandstone indicating interglacial. The sandstone is rich in cold water fossils like brachiopods.

The Chuping Formation is named after Chuping Hill in Perlis (Jones, 1961). The total thickness of the formation is estimated to be 750-900 m. It is mainly made of Permian and Triassic crystalline limestone (Figs 15, 16). The upper part of the formation was affected by the metamorphism. It resulted in a lack of any fossils in this part of the formation. In many places, the top of the formation had been faulted under the older Setul Formation, for instance at Kechil Pulau (Fig. 17). The Chuping Formation is not as rich in karst form as the Setul Formation, but still extensive dissolution of limestone and marble has resulted in beautiful karst shapes, such as the Dayang Bunting Lake, which is a collapsed cave filled with fresh water and sea-notches, sea-caves, sea-stacks, sea-arches.

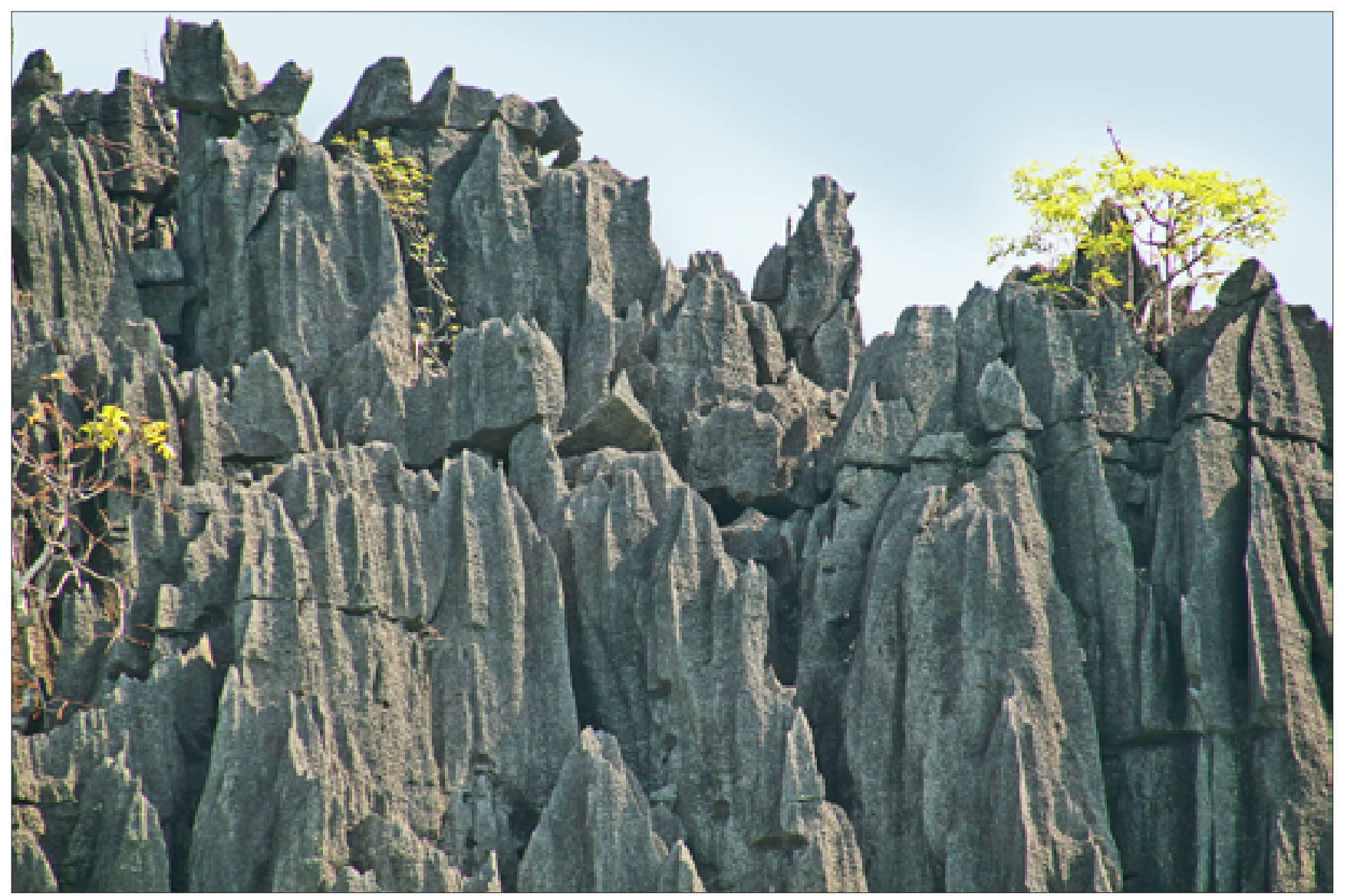

Fig. 12. Karst pinnacles, photo M. Mordal 


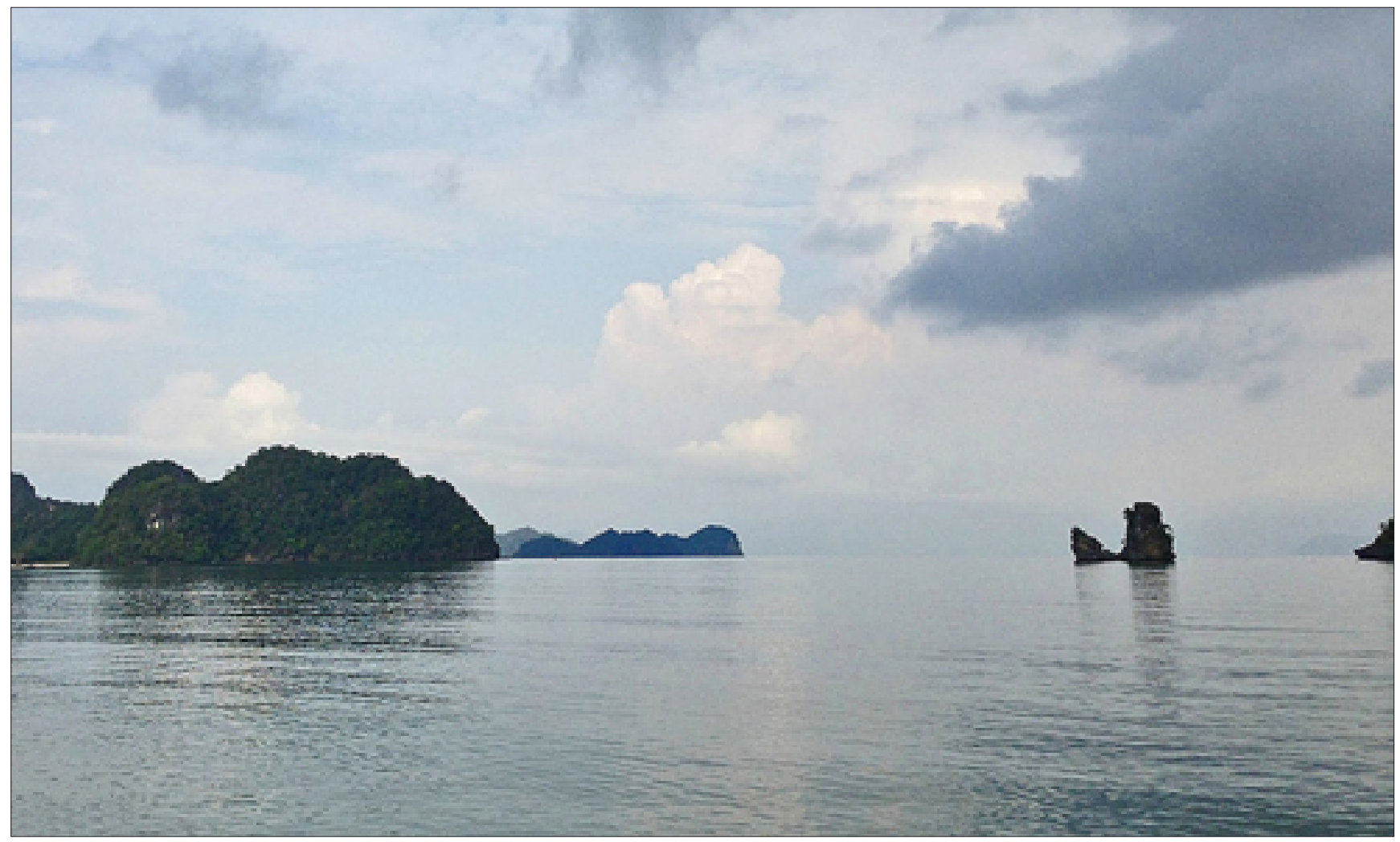

Fig. 13. Tanjung Rhu - sea stack, photo D. Again

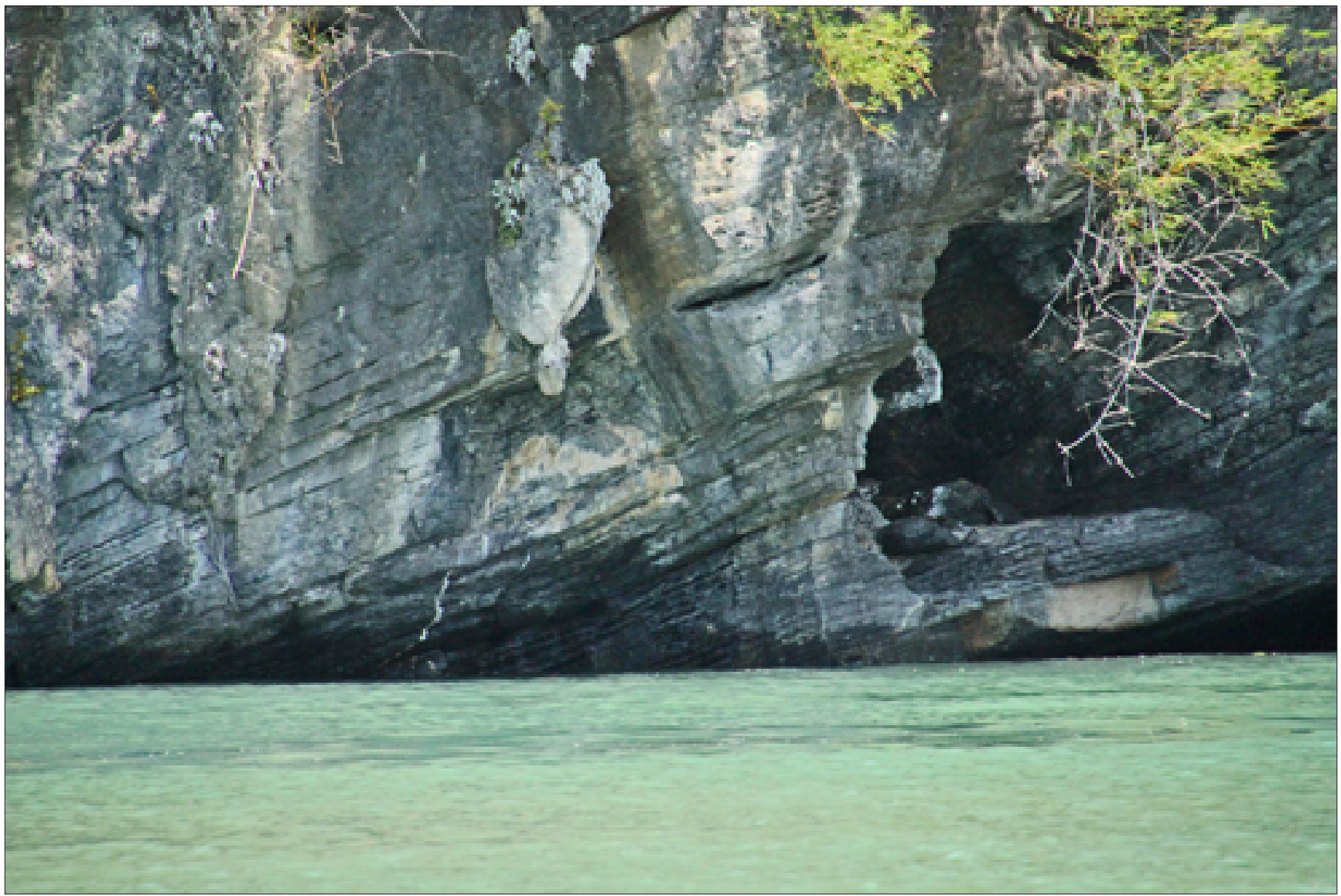

Fig. 14. Sea caves and sea notches, photo M. Mordal 


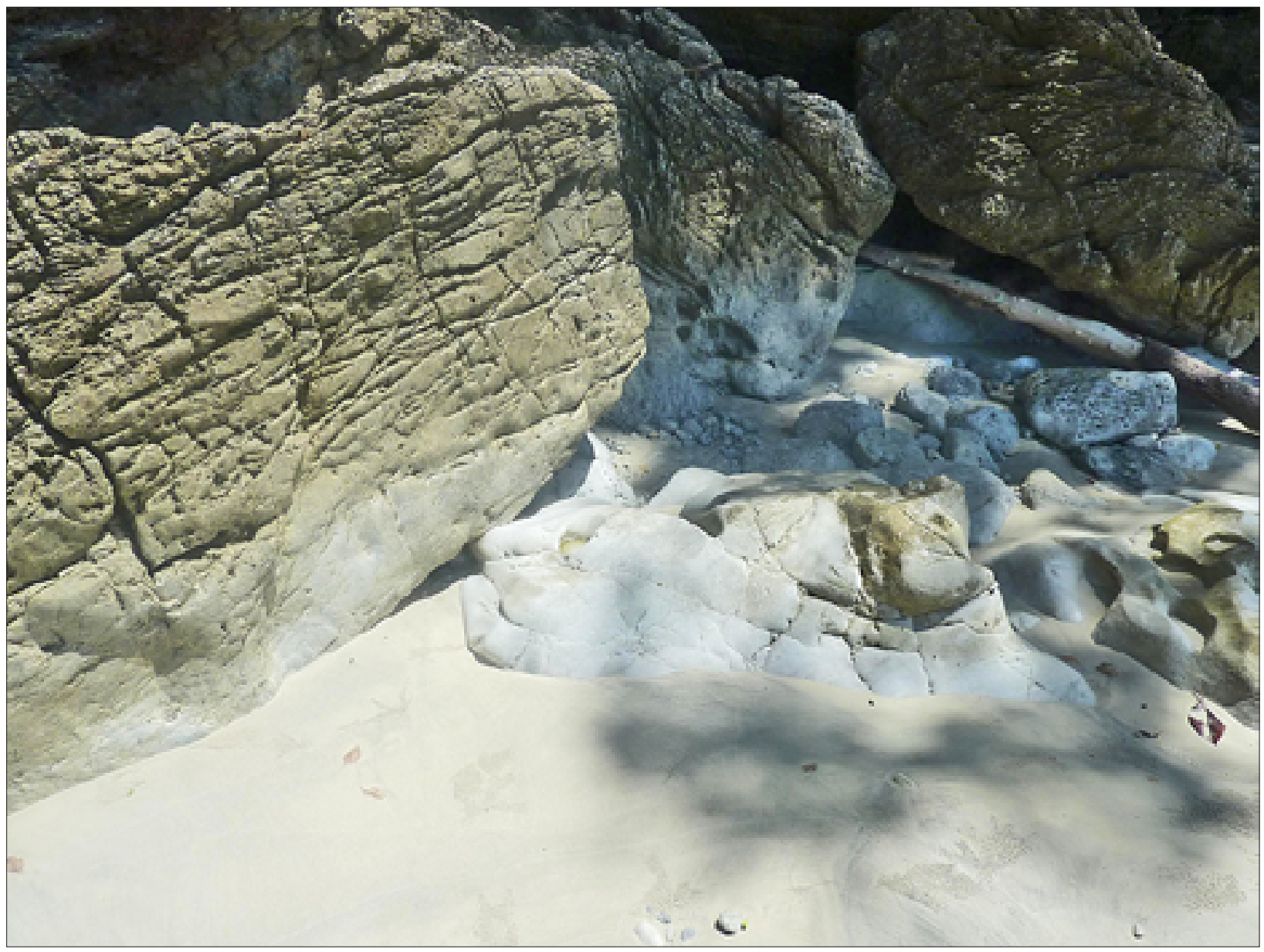

Fig. 15. Partly metamorphosed limestones, photo M. Mordal

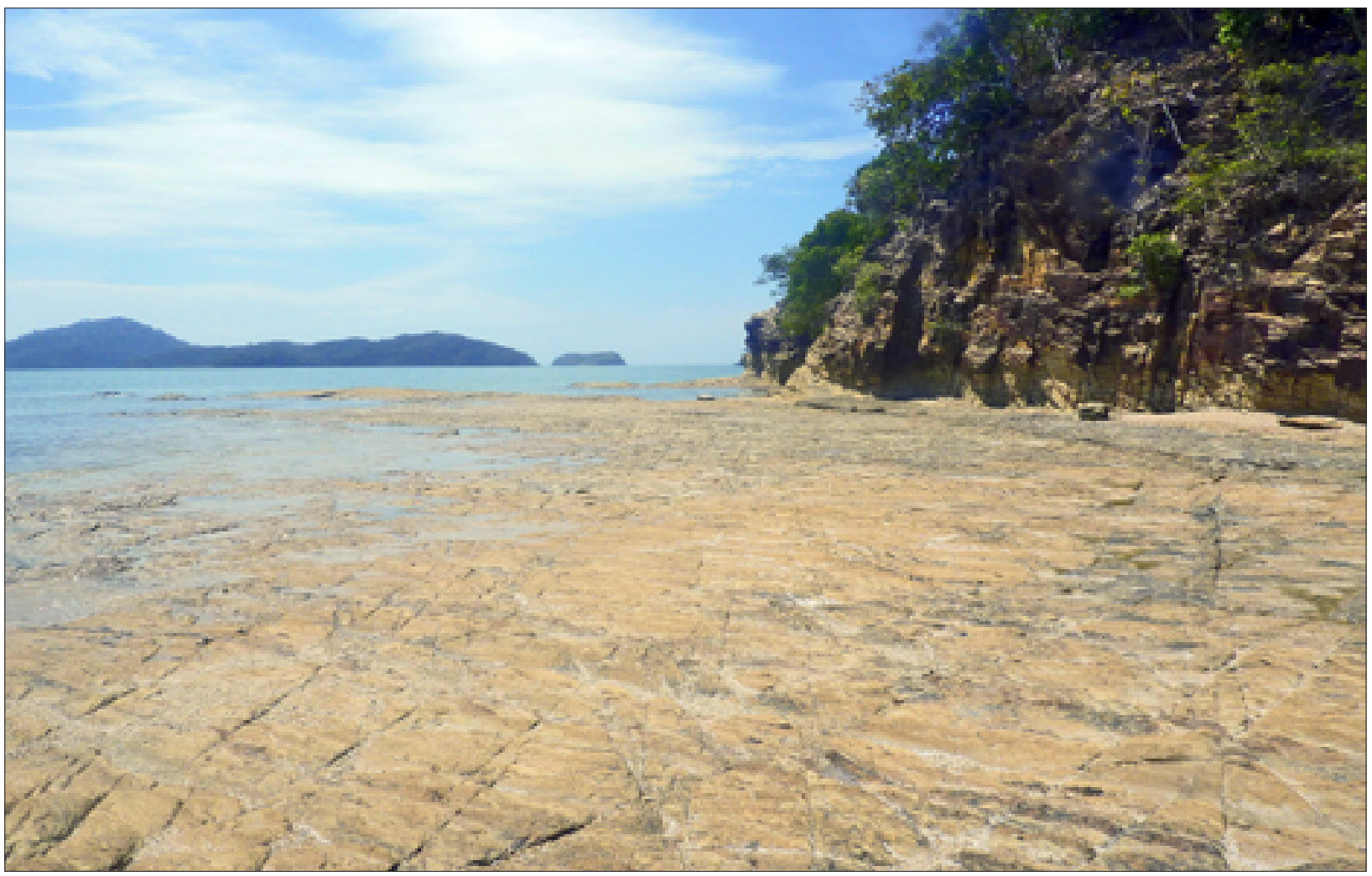

Fig. 16. Raised wave-cut platform at Pulau Ular, photo M. Mordal 


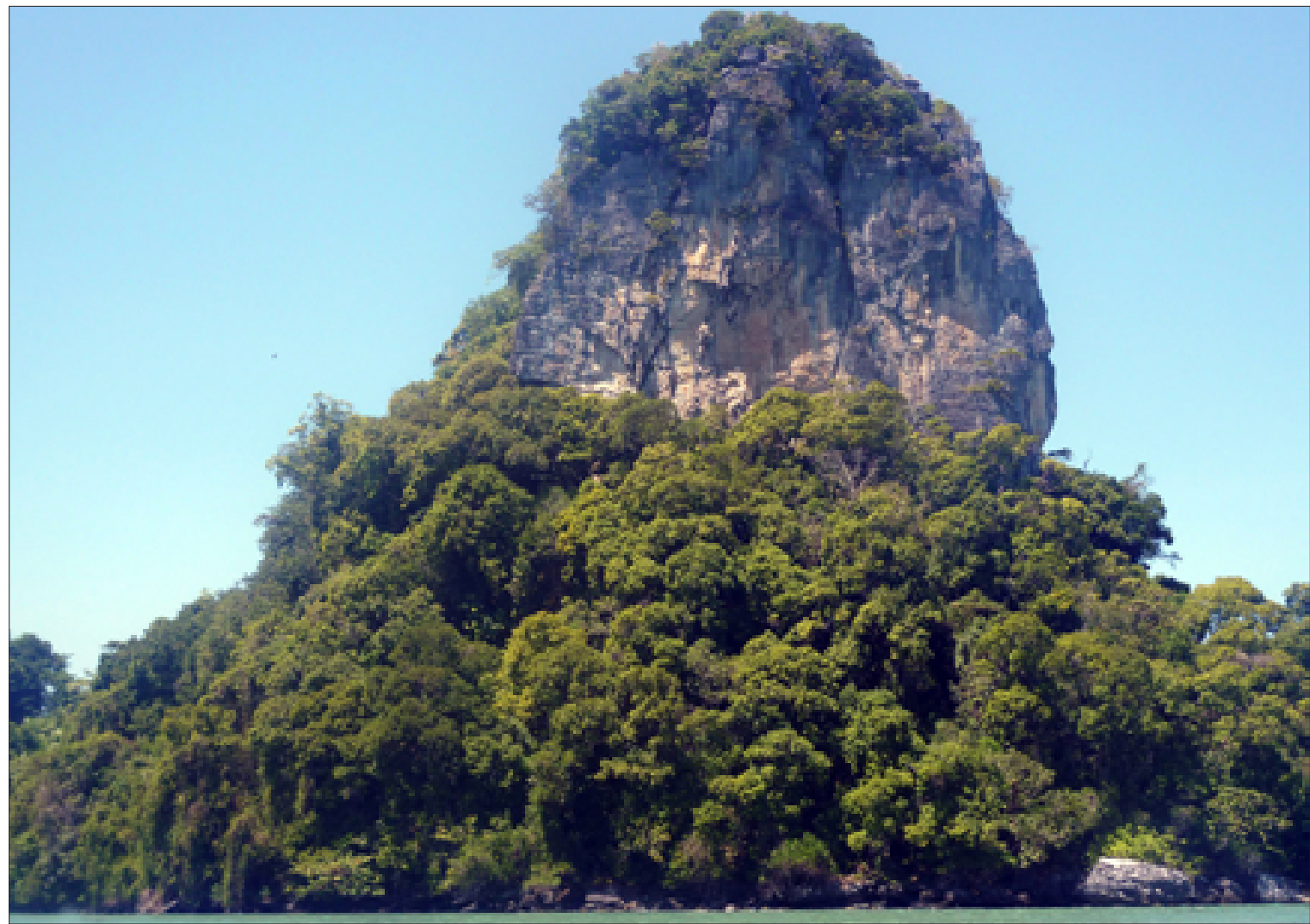

Fig. 17. Limestone and marble mogote of Pulau Singa Kechil, photo M. Mordal

Granite is found mainly on all three populated islands, namely Pulau Langkawi, Pulau Dayang Bunting and Pulau Tuba. The intrusive igneous rock is found scattered throughout the archipelago in the form of large and small igneous stocks. The age of the Langkawi granite has been established as Triassic (Bignell, Snelling, 1977). Several intrusions of granite brought about some new minerals, such as zircon and tourmaline and metamorphosis of host rocks. Quaternary, unconsolidated sediments are the youngest unit in Langkawi archipelago geology. They mainly consist of river alluvium (Kilim), coastal (Panati Chenang) and mangroves plain (Kilim).

Geological resources are nonrenewable and may disappear if they are not looked after. Trying to achieve economic benefits without damaging the natural environment, the Geological Heritage Group of Malaysia identified 90 geosites in Langkawi with heritage values. It also helped to create the Langakwi Geopark, which was accepted as a member of a Global Geopark Network, on 1st of June 2007. Some of the identified geosites have been described well, while other are still under study (Che Aziz et al., 2008)

Some of them are grouped in larger geoforest parks and others are outside of these parks and classified as geological monuments or protected geosites. Presently, there are 3 geoforest parks (www 11) (Fig. 18), 3 geological monuments and 10 protected geosites. In each geoforest, there is a suggested trail to see the most spectacular and geologically interesting nature.

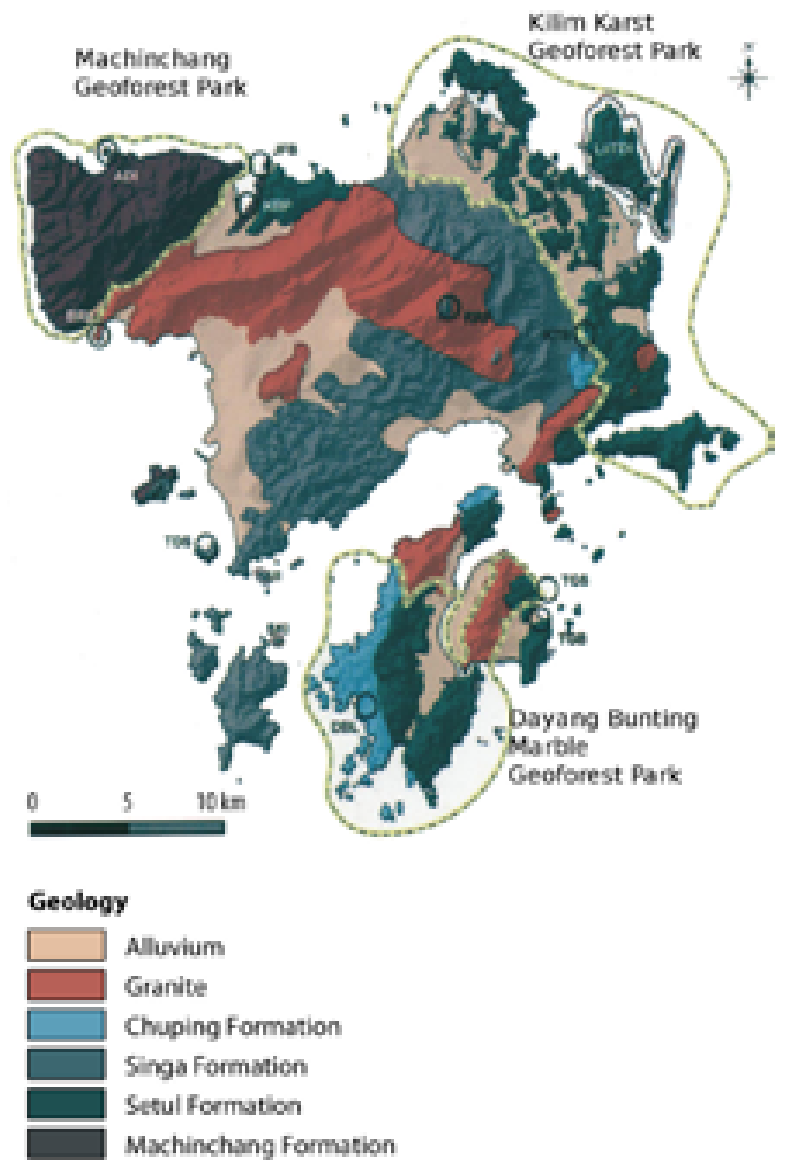

Fig. 18. The range of Langkawi Geoprak devided into smaller Geoforest units, (source: www 11) 


\section{Infrastructure of Langkawi Geopark}

The infrastructure for tourism and education is already well developed, and it has been going through constant change towards the better. Development in Langkawi is guided by the Langkawi Structure Plan (LSP), that considers the need for sustainable development of the islands. LSP divides the infrastructure into 3 main categories: urbanization and settlement, tourism infrastructure and nature conservation and agriculture areas. Every investment that is undertaken on the island is obliged to follow criteria such as minimal damage to the environment, blending with nature, use of natural materials and environmentally friendly technologies.

Education, including dissemination of knowledge has been given particularly high priority in the Langkawi Islands. To implement mentioned assumptions the following entities were established:

Geopark Information Centre (Fig. 19) is situated in Oriental Village, next to Machinchang. It provides information on the Langkawi Geopark. On display, are examples of rocks and fossils from all around the Langkawi Islands. Geological maps and posters are also available. Brochures can be collected from this place. Unfortunately, the person working in Geopark Information Centre does not speak even basic English and often the office is closed or empty.
The Langkawi Research Centre is the scientific office for the Langkawi Geopark. It concentrates on multidisciplinary research, for instance: Geology and Landscape, Biology and Marine and Cultural and Local Tradition Programmes. Yet, the office again is open during very limited hours and not necessarily those that are pointed on the door. Inside, there is a collection of books on Langkawi that can be bought in this place (Fig. 20).

Geotrails and geoproducts are widely spread on the Langkawi Islands. There are over 90 geosites and most of them are connected into geotrails. The geosites as well as geotrails are exposed to the public for educational and touristic purposes. They widen the knowledge about the islands and geology itself. Currently, island hopping and walking geotrails are the most popular. While following the geotrail, the tourist is guided by tour-guides, well described information boards including general boards and those about certain geosites. Unfortunately, again tour guides do not have even basic knowledge of the English language, and they do not want to follow the geotrails. They rather prefer to use usual beaten tracks (Figs 21, 22)

Generally concluding, the infrastructure of Langkawi Islands is developed very well in terms of material resources such as the $360^{\circ}$ scenic platform (Fig. 23), scenic sky-bridge (Fig. 24), jetties in places of necessity, general information boards, information boards for particular geosites, access to boats, kayaks etc., brochures, leaflets.

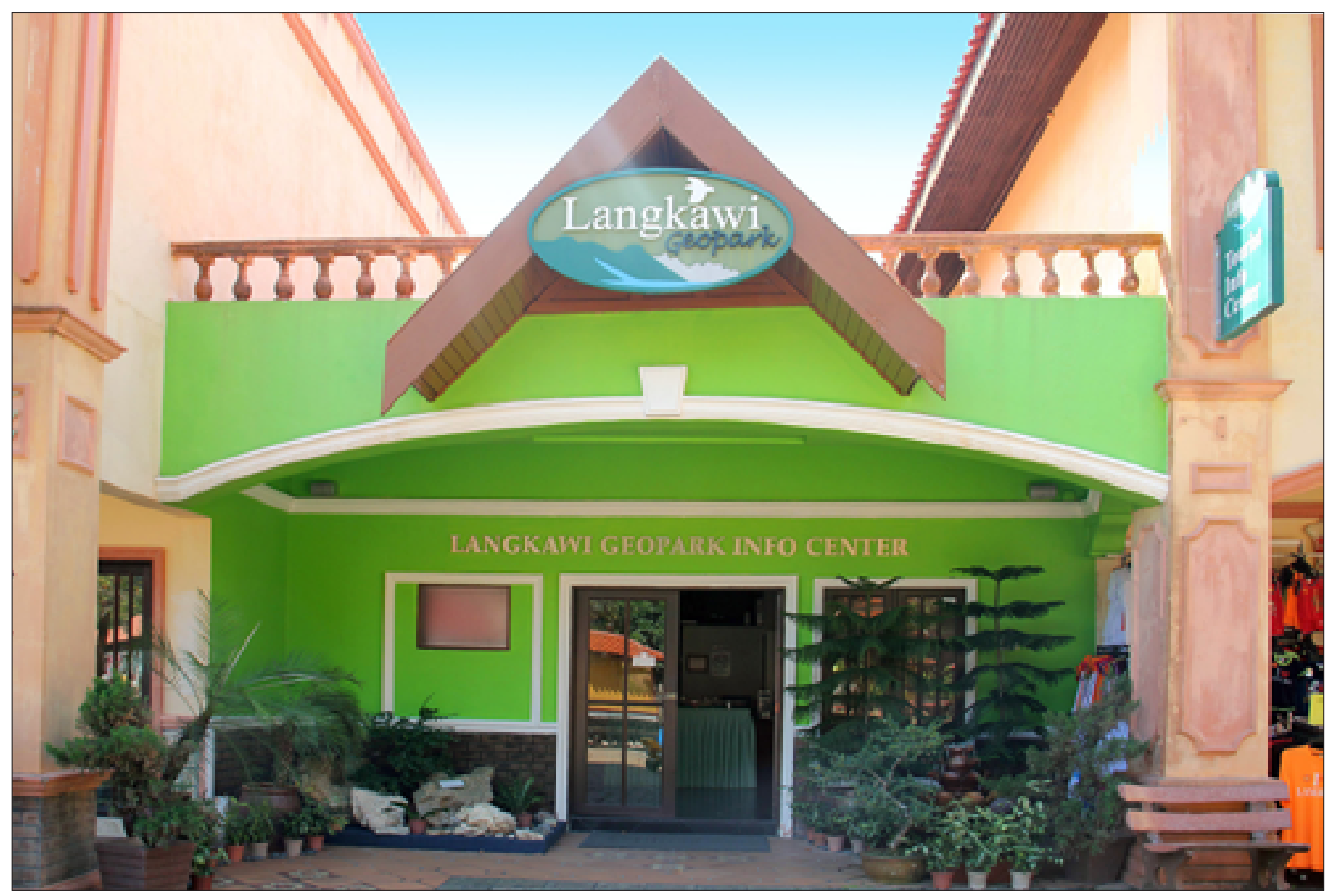

Fig. 19. Geopark Information Centre, photo M. Mordal 


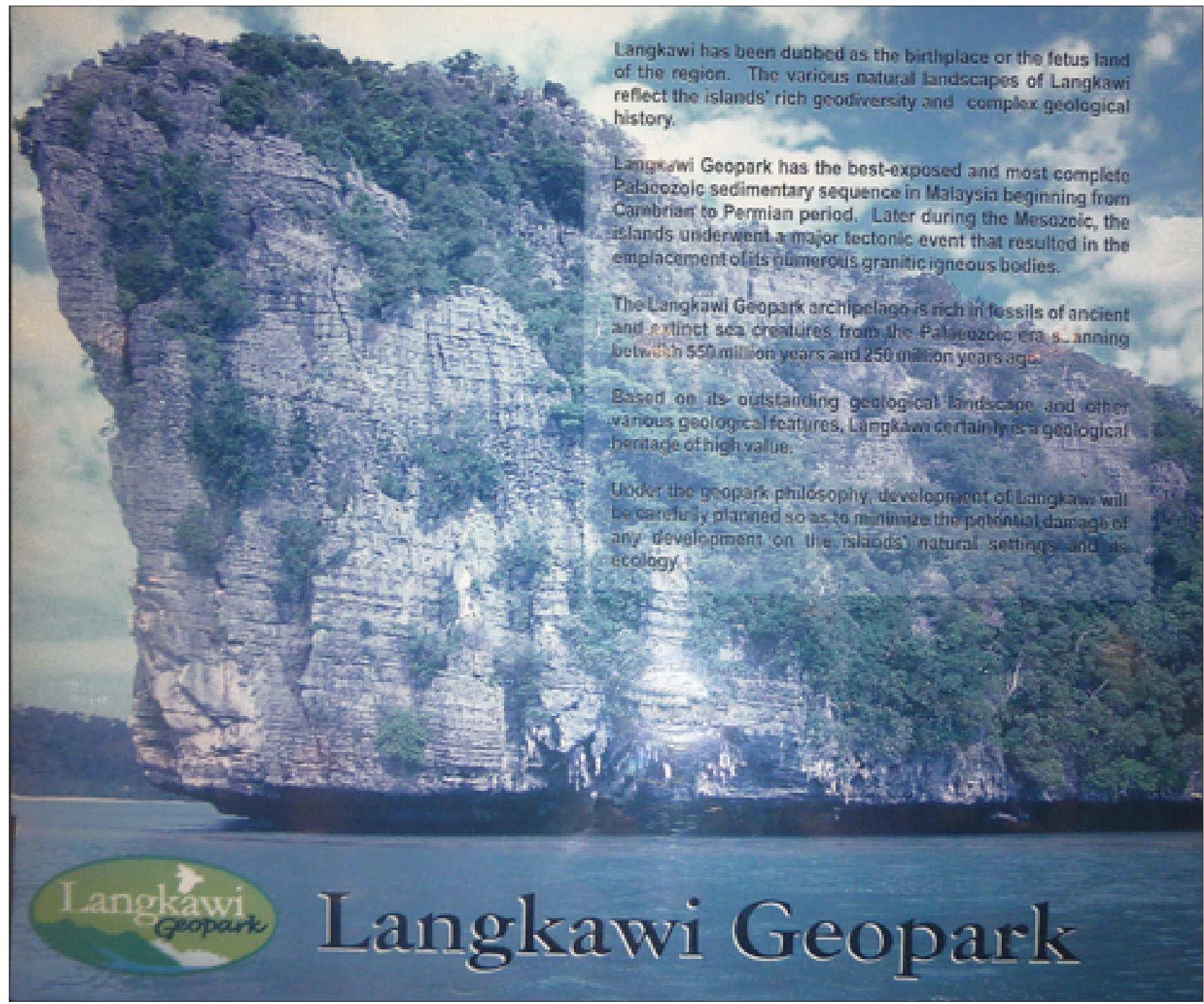

Fig. 20. Poster inside the Geopark Information Centre, photo M. Mordal

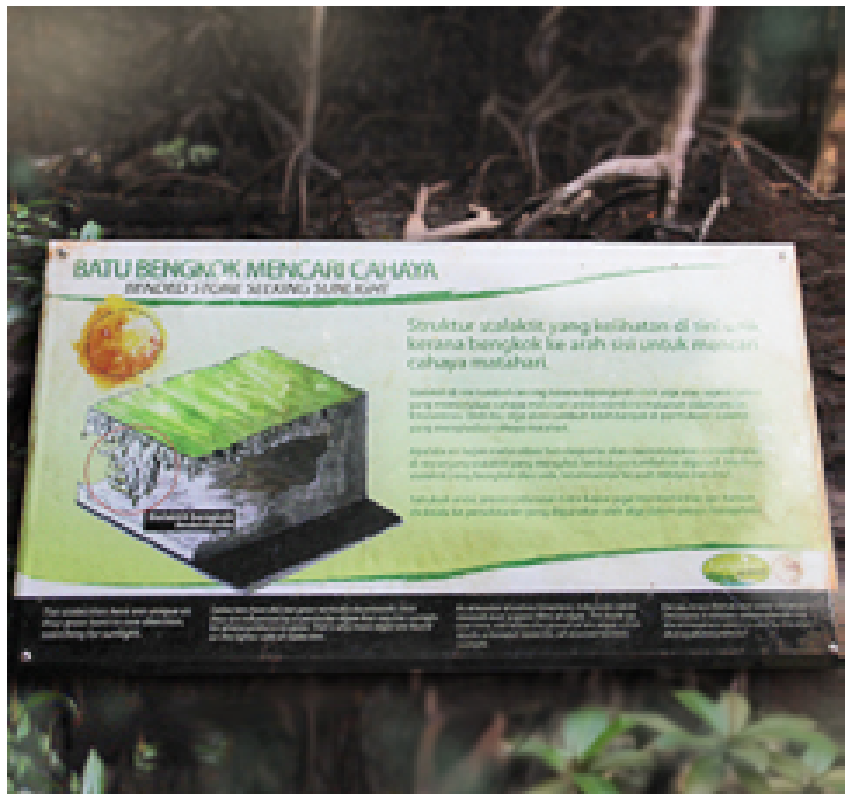

Fig. 21. Geosite information board, photo M. Mordal

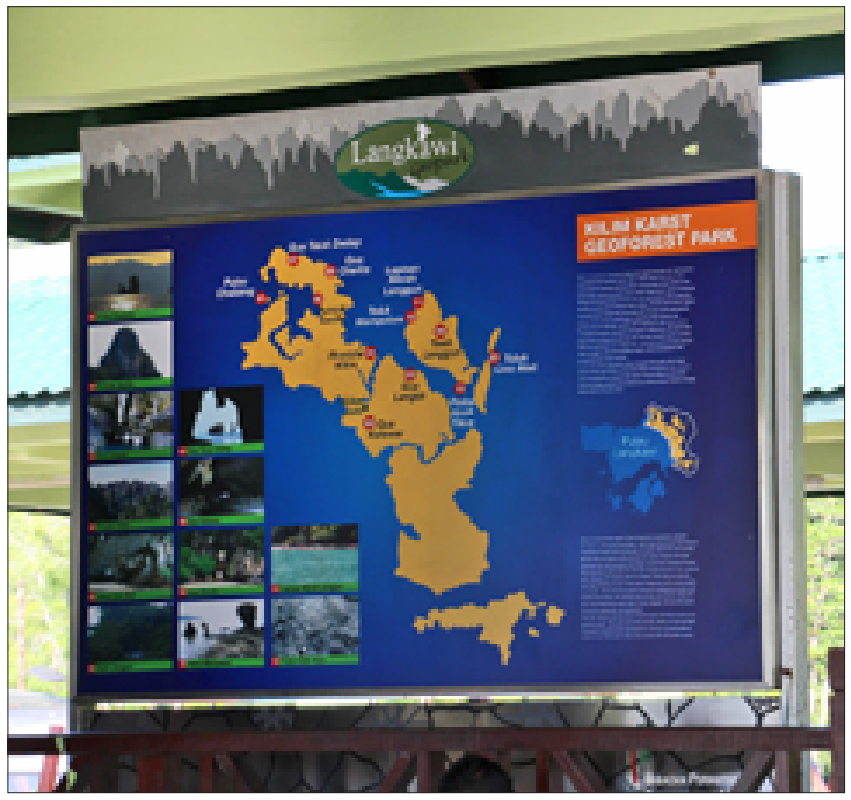

Fig. 22. Geotrail information board, photo M. Mordal 


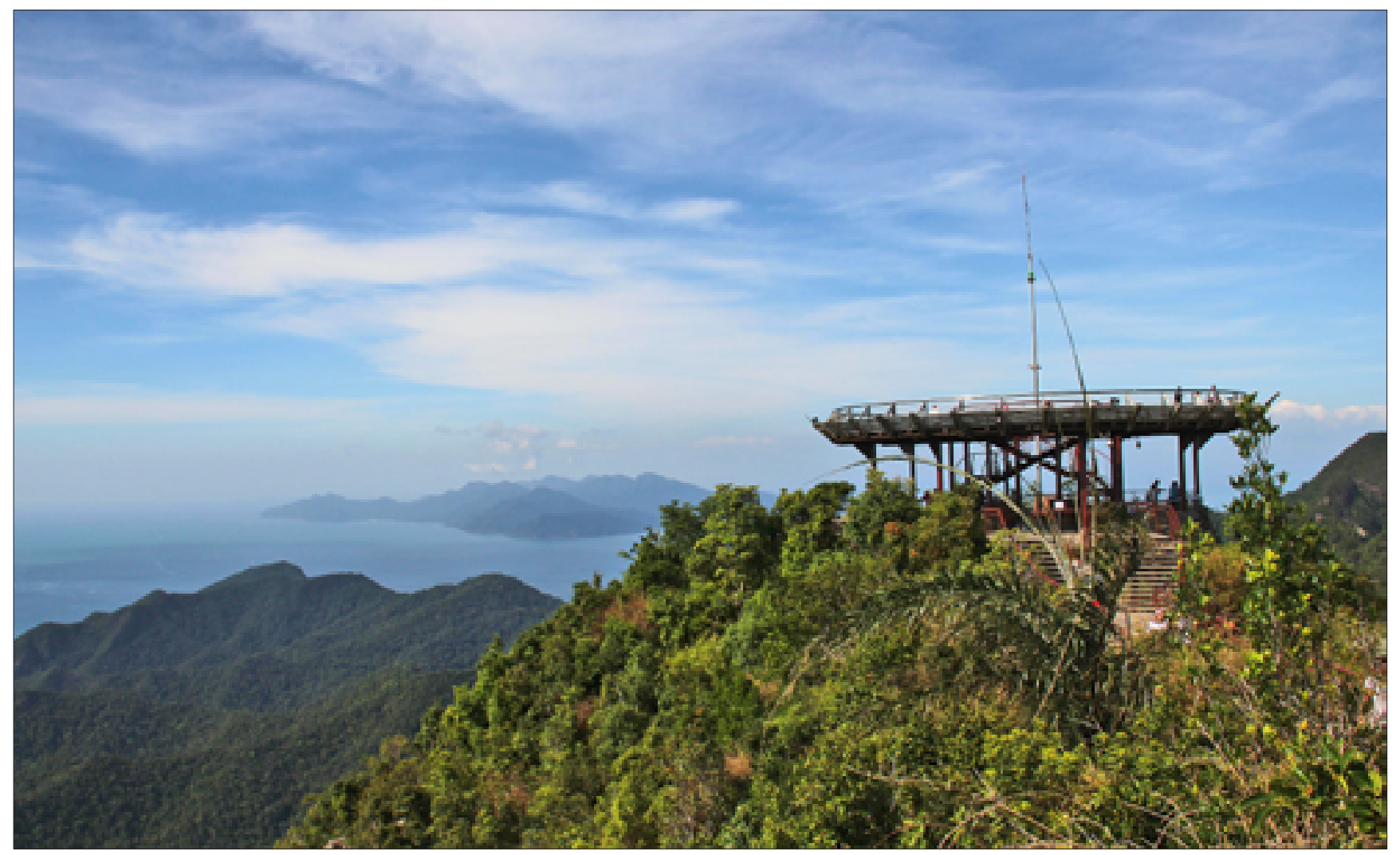

Fig. 23. $360^{\circ}$ Scenic platform, photo M. Mordal

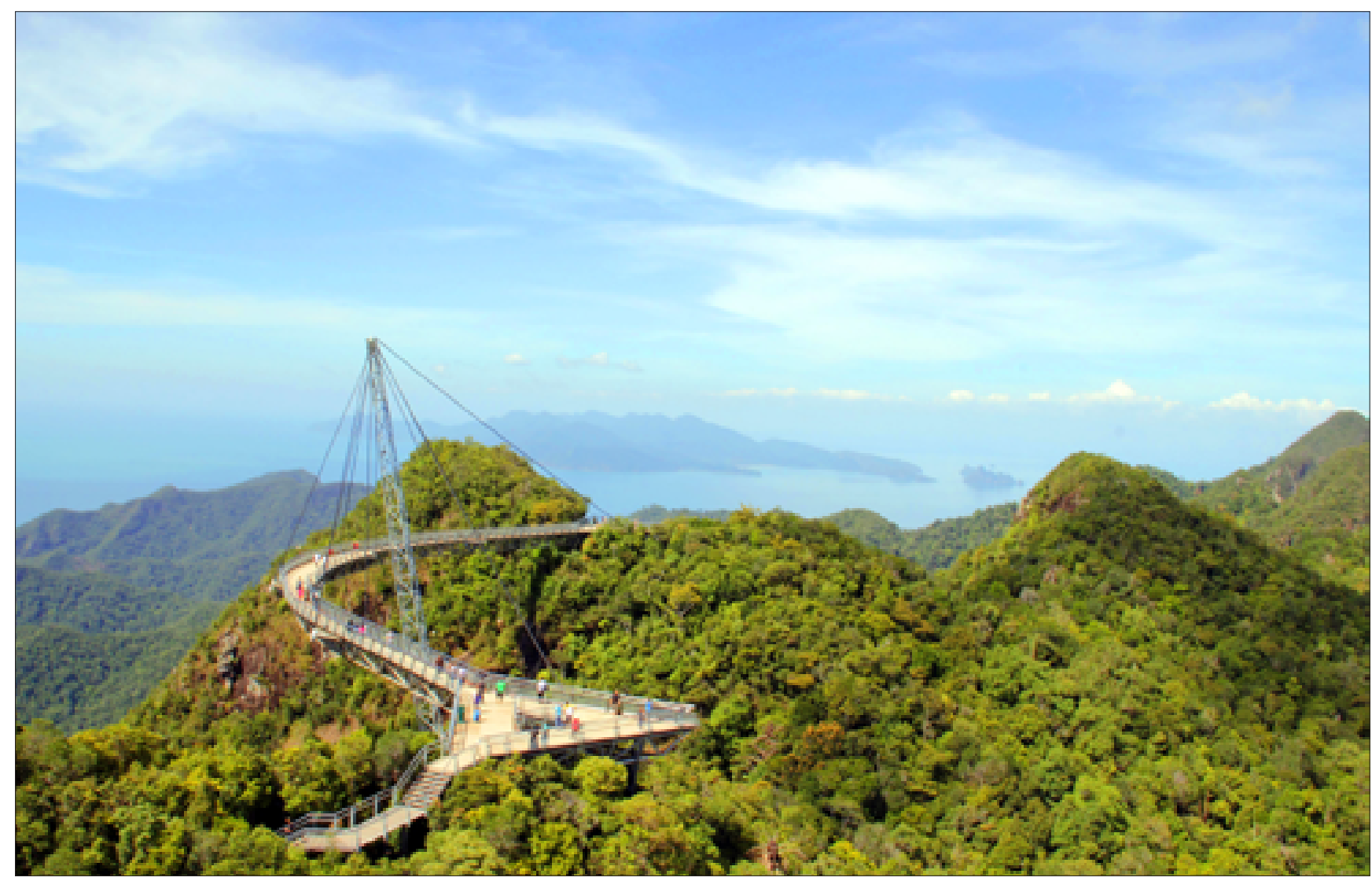

Fig. 24. Scenic sky-bridge, photo M. Mordal 


\section{Conclusions}

The Malaysian government understood the tendency towards growing geotourism before other countries in the region. Malaysia could also be called the pioneer in ecotourism and geotourism on a global scale by starting ecotourism planning in the 1990s. There is still a big gap between legislation and the common understanding of ecotourism generally and geotourism particularly among the citizens.

The Langkawi Islands possess enormous potential for the development of geotourism. They not only hold all the major rock types, beginning with those from the Cambrian period, such as fossils and faults. In addition, the most important is the fact that all those geological features are exposed well and are easy to reach since the infrastructure on the island is developed excellently.

\section{Acknowledgements}

First and foremost, I would like to thank to my supervisor of this paper, Prof. Dr. W. Florek for the valuable guidance and advice. Besides, I would like to thank the authority of Langkawi Geopark for the possibility to obtain the necessary references and do the field research. Also, I would like to take this opportunity to thank Mr. N. Petit for language consultation and advise. Finally, an honorable mention goes to my family, especially Ms. A. Mordal (mother), Ms. Z. Kulka (grandmother), Ms. K. Kulka (sister), Mr. M. Mordal (brother), Ms. M. Kasicka (friend) for practical help in organizing the trip to Malaysia, looking after my son Alex in Malaysia, help with editing and mostly for their understanding and support on completing this project. Without the help of the particular people mentioned above, I would have faced many difficulties while executing the project.

\section{References}

Bignell J.D., Snelling N.J., 1977. Geochronology of Malayan granites. Overseas Geology and Mineral Resources, 47: 1-72.

Che Aziz A., Kamal R.M., Mohd S.L., Ibrahim K., Tanot U., 2008. Field Guide to Geology of Langkawi Geopark, Kuala Lumpur, Malaysia.

Daniel E.G.S., Nadeson T., 2006. WWF-Malaysia and the Malaysian Public Universities towards Action for EfSD. Proceedings of the 2006 ASAIHL Conference on Education for Sustainable Development [EfSD], June 19-22, 2006 Penang, Malaysia.

Jones C.R., 1961. A revision of the stratigraphical sequence of the Langkawi Islands, Federation of Malaya. Proceedings. Ninth Pacific Science Congress, 12: 287-300.

Jones C.R., 1981. Geology and mineral resources of Perlis, North Kedah and the Langkawi Islands. Geological Survey Malaysia District Memoir, 17, 275 pages (includes a detailed geological map of Langkawi).

Lee C.P., 1983. Stratigraphy of the Tarutao and Machinchang formations. In Nutalaya P. (ed.), Proceedings of Workshop on Stratigraphic Correlation of Thailand and Malaysia. Geological Society of Thailand and Malaysia, Bangkok: 20-38.

Leman M.S., Komoo, I., Mohamed K.R., Ali C.A., Unjah T., 2007. Geopark as an answer to geoheritage conservation in Malaysia - The Langkawi Geopark case study, Institute of Environment and Development, University Kebangsaan, Malaysia.
Leman M.S., Komoo I., Mohamed K.R., Ali C.A., Unjah T., Othman K., Yasin M.H.M., 2008. Geology And Geoheritage Conservation Within Langkawi Geopark, Malaysia, http://www.globalgeopark.org/articles/6337.htm

Marker M.A., Blanco A., Lokanathan S., Verma A., 2008. Ecotourism in Malaysia. In: Clusters and National Competitiveness, Lee Kuan Yew School of Public Policy, Malaysia.

\section{Websites}

www 1 - www3.weforum.org/docs/WEF_TravelTourismCompetitiveness Report_2007.pdf

www 2 - $\bar{k}$ kyspp.nus.edu.sg/aci/wpcontent/uploads/sites/4/2013/04/Ecotourism in Malaysia 2008 Paper.pdf

www 3 - www.epu.gov.my/en/seventh-malaysia-plan-1996-2000

www 4 - www.epu.gov.my/en/eighth-malaysia-plan-2001-2005

www 5 - www.epu.gov.my/en/ninth-malaysia-plan-2006-2010

www 6 - www.wttc.org

www 7 - www.google.pl/maps

www 8 - www.forestry.gov.my/index.php/en

www 9 - www.lada.gov.my/v2/en/

www 10 - www.statistics.gov.my

www 11 - www.ukm.my/wgm/pdf/preview_buku_Langkawi\%20Geopark geosite.pdf 